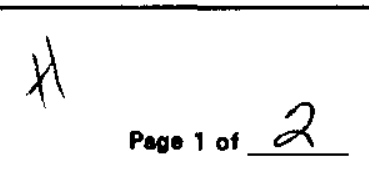

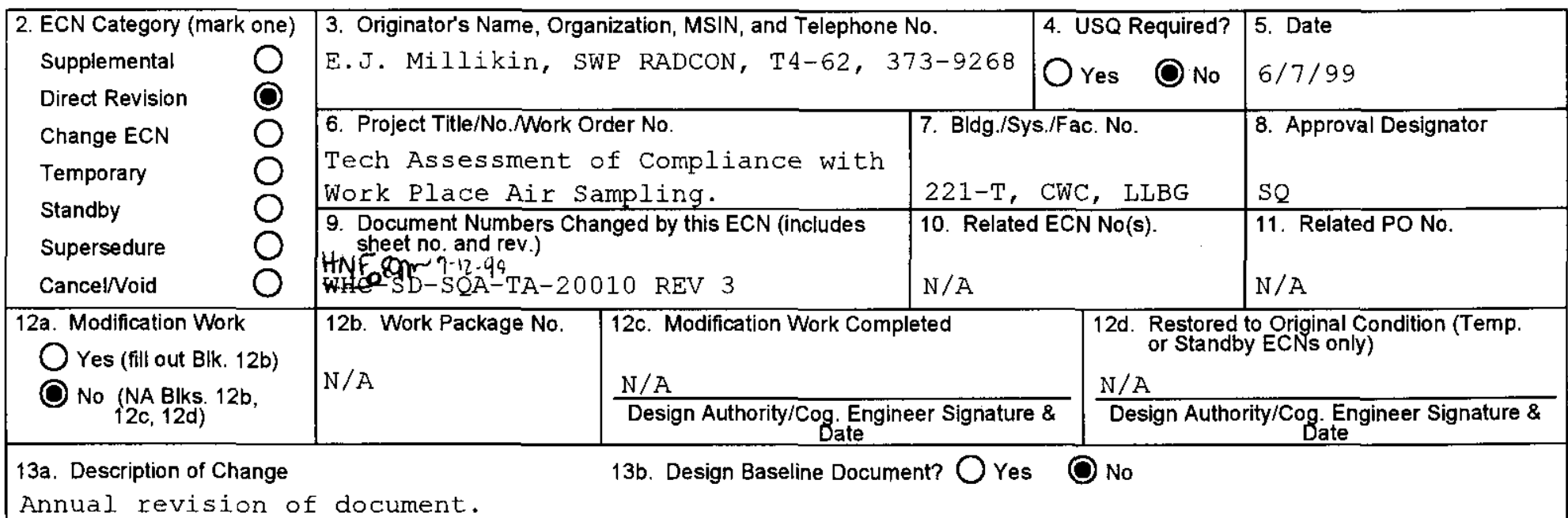

\begin{tabular}{|l|l|l|}
\hline 14a. Justification (mark one) & 14b. Justification Details \\
Criteria Change & $\mathrm{O}$ & Annual review of document. \\
Design Improvement & $\bigcirc$ & \\
Environmental & & \\
Facility Deactivation & & \\
As-Found & $\bigcirc$ & \\
Facilitate Const. & $\bigcirc$ & \\
Const. Error/Omission & $\bigcirc$ & \\
Design Error/Omission & $\mathrm{O}$ & \\
\hline
\end{tabular}

15. Distribution (inclucle name, MSIN, and no. of copies)

B.L. Baumann T4-04, 1

J.L. Miller T3-28, 1

R.W. Whitlock T4-03, 1

E.J. Millikin, T4-62, 1

D.L. Vance, T4-06, 1

Central Files, B1-07, 1

DOE/RL Reading Room, H2-53, I

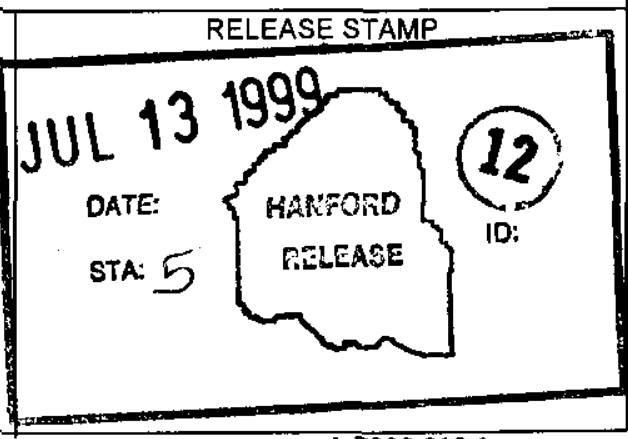




\section{ENGINEERING CHANGE NOTICE}

\begin{tabular}{l|l} 
Page 2 of 2 & $\begin{array}{l}\text { 1. ECN (use no. from pg. 1) } \\
650961\end{array}$ \\
A & $\begin{array}{l}\text { 18. Schedule Impact (days) } \\
\text { Improvement } \mathrm{O} N \mathrm{~N} / \mathrm{A}\end{array}$ \\
Delay & $\mathrm{O}$
\end{tabular}

16. Design Verification Required

\section{Ores \\ O No}

17. Cost Impact

ENGINEERING

Additional $\bigcirc \$ N / A$

Savings $O \$ N / A$

\section{CONSTRUCTION}

Additional $\bigcirc \$ N / A$

Savings

) $\$ N / A$

will be affected by Change Impact Review: Indicate the related documents (other than the engineering
the change described in Block 13 . Enter the affected document number in Block 20 .

\section{SDD/DD}

Functional Design Criteria Operating Specification Criticality Specification Conceptual Design Report Equipment Spec.

Const. Spec.

Procurement Spec.

Vendor Information

OM Manual

FSAR/SAR

Safety Equipment List

Radiation Work Permit

Environmental Impact Statement

Environmental Report

Environmental Permit $\square$ Seismic/Stress Analysis

Stress/Design Report

Interface Control Drawing

Calibration Procedure

Installation Procedure

Maintenance Procedure

Engineering Procedure

Operating Instruction

Operating Procedure

Operational Safety Requirement

IEFD Drawing

Cell Arrangement Drawing

Essential Material Specification

Fac. Proc. Samp. Schedule

Inspection Plan

Inventory Adjustment Request $\square$
$\square$
$\square$
$\square$
$\square$
$\square$
$\square$
$\square$
$\square$
$\square$
$\square$
$\square$
$\square$
$\square$
$\square$
$\square$
Tank Calibration Manual Health Physics Procedure Spares Multiple Unit Listing Test Procedures/Specification Component Index ASME Coded ltem Human Factor Consideration Computer Software

Electric Circuit Schedule ICRS Procedure

Process Control Manual/Plan Process Flow Chart

Purchase Requisition

Tickler File

$\mathrm{N} / \mathrm{A}$

$\square$
$\square$
$\square$
$\square$
$\square$
$\square$
$\square$
$\square$
$\square$
$\square$
$\square$
$\square$
$\square$
$\square$
$\square$

20. Other Affected Documents: (NOTE: Documents listed below will not be revised by this ECN.) Signatures below indicate that the signing organization has been notified of other affected documents listed below.

21. Approvals

\section{Signature}

Date

Design Authority

Cog. Mgr. J.R. Rosser

QA

Safety

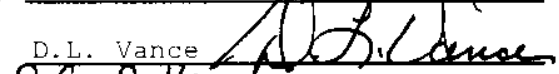

B.G. Baker

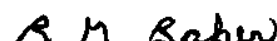

Environ.

Other

J.L. Miller

nf́ E.J. Adams

Gqhallekin

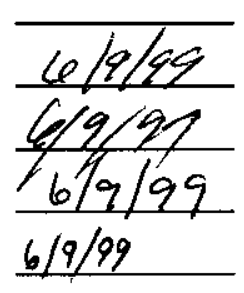

$6 / 9 / 99$

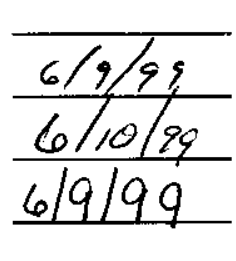

Signature

Date

Design Agent

$P E$

QA

Safety

Design

Environ.

Other

\section{DEPARTMENT OF ENERGY}

Signature or a Control Number that tracks the Approval Signature

\section{ADDITIONAL}

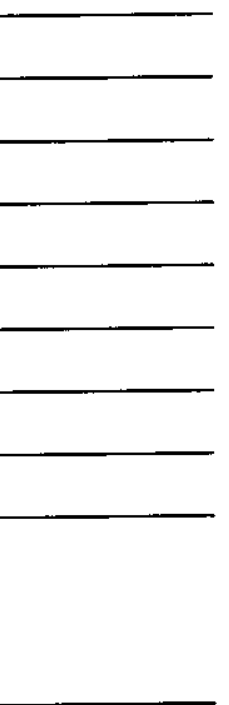




\title{
Technical Assessment of Compliance with Work Place Air Sampling Requirements at Solid Waste Project
}

\author{
E.J. Millikin \\ Waste Management Federal Services of Hanford, Inc. Richland, WA. 99352 \\ Richland, WA 99352 \\ U.S. Department of Energy Contract DE-AC06-96RL13200

$\begin{array}{ll}\text { EDT/ECN: } & 650961 \\ \text { Org Code: } & 32 \mathrm{~A} 50 \\ \text { B\&R Code: } & \mathrm{N} / \mathrm{A}\end{array}$ \\ UC: $\quad$ N/A \\ Charge Code: 101599 \\ Total Pages: 19 \\ Key Words: 221-T, T Plant, 2706-T, 2706-TA, Burial Grounds, Central Waste \\ Complex,
}

Abstract: Annual revision to work place air sampling document for SWP.

TRADEMARK DISCLAIMER. Reference herein to any specific commercial product, process, or service by trade name, trademark, manufacturer, or otherwise, does not necessarily constitute or imply its endorsement, recommendation, or favoring by the United States Government or any agency thereof or its contractors or subcontractors.

Printed in the United States of America. To obtain copies of this document, contact: Document Control Services, P.O. Box 950, Mailstop H6-08, Richland WA 99352, Phone (509) 372-2420; Fax (509) 376-4989.

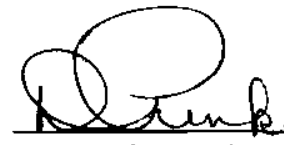

Release Approval

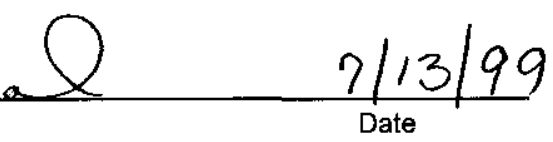

Approved For Public Release

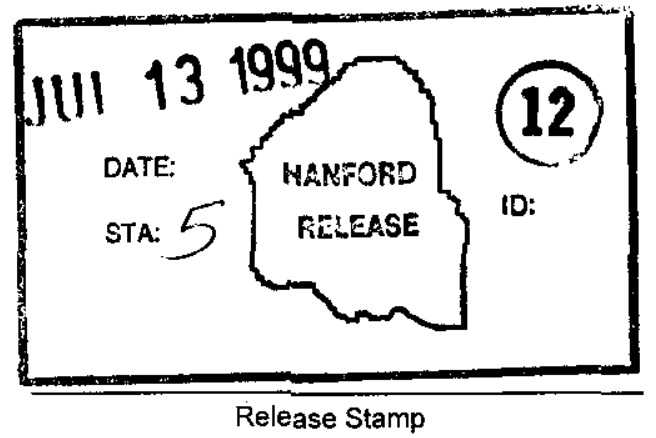

Release Stamp 


\section{RECORD OF REVISION}

(1) Document Number HNF $60 M 711279$ FDHRSD-SQA-TA20010. Rev. 4
Page 1 of 1

(2) Title

Technical Assessment of Compliance with Work Place Air Sampling Requirements at Solid Waste Project Management.

CHANGE CONTROL RECORD

(3)

Revision

3

RS 4
(4) Description of Change - Replace. Add, and Delete Pages

(7) Annual revision to document. Submitted per ECN 637391.

(7) Annual revision to document. Submitted per ECN 650961 .
Authorized for Release

\begin{tabular}{l|l} 
(5) Cog. (6) Cog. Mgr. Date \\
\hline
\end{tabular} Engr.

M. Irwin $2 / 2 / 98$

RW Whitlock

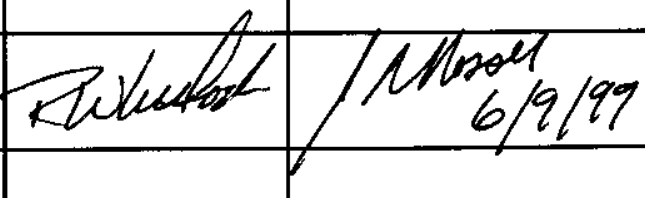




\section{CONTENTS}

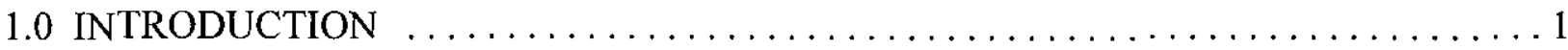

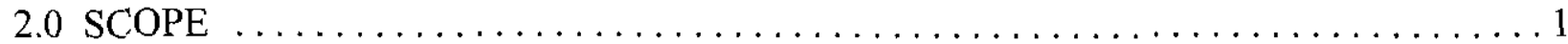

3.0 TECHNICAL BASIS FOR REQUIRING WORK PLACE AIR MONITORING $\ldots \ldots \ldots 1$

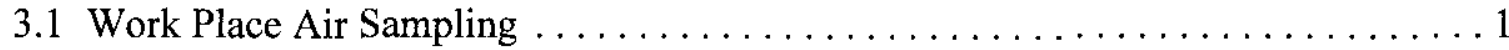

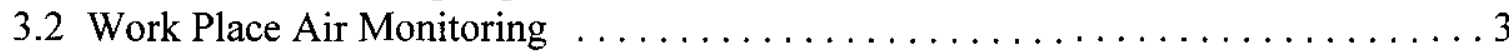

4.0 SOLID WASTE PROJECTS OPERATIONS $\ldots \ldots \ldots \ldots \ldots \ldots \ldots \ldots \ldots \ldots \ldots$

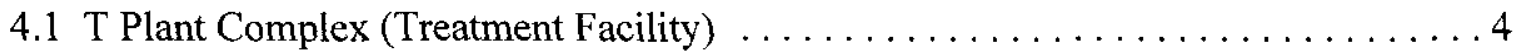

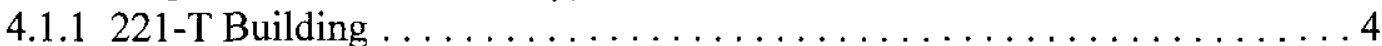

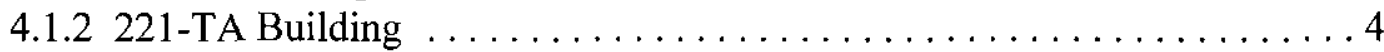

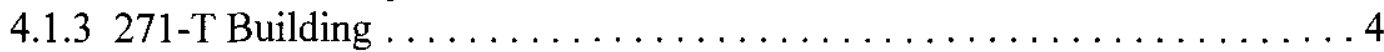

4.1.4 2706-T, 2706-TA, 2706-TB Building $\ldots \ldots \ldots \ldots \ldots \ldots \ldots \ldots \ldots$

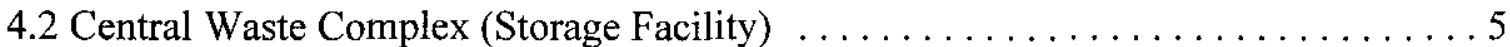

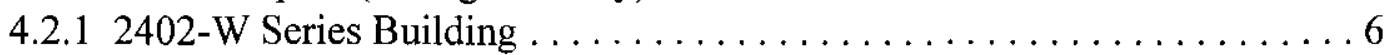

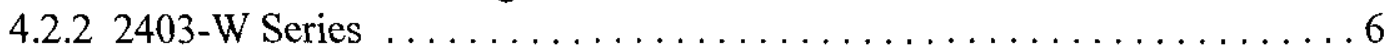

$4.2 .32404-W$ Series . . . . . . . . . . . . . . . . . . . . . . . . 6

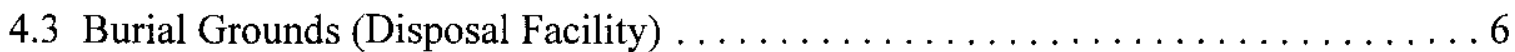

5.0 WORK PLACE AIR MONITORING EVALUATION $\ldots \ldots \ldots \ldots \ldots \ldots \ldots \ldots \ldots \ldots$

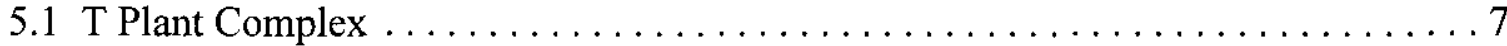

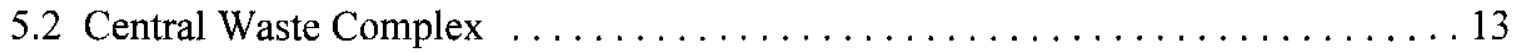

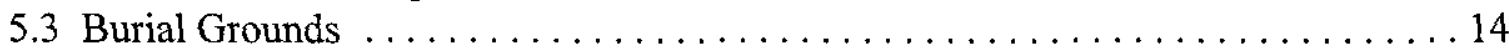

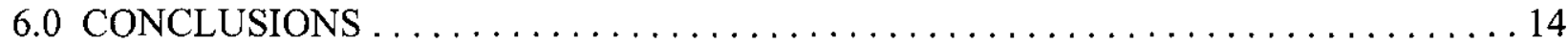

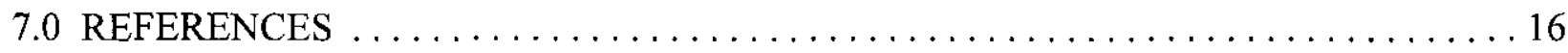




\subsection{INTRODUCTION}

Article 704 (e) of Title 10, Code of Federal Regulations, Part 835 (10 CFR 835) states that changes in equipment, techniques, and procedures used for monitoring in the work place shall be documented. Fluor Daniel Hanford, Inc. (FDH) has committed to complying with this requirement through the Fluor Daniel Hanford Radiation Protection Program, Implementation of Title 10, Code of Federal Regulations, Part 835 (FDH 1997a) (RPP) and the Hanford Site Radiological Control Manual (HSRCM). Both the RPP and HSRCM require the Radiological Control Organization to perform and document a review of the adequacy of sampling and monitoring systems as part of any facility or operational changes affecting radiological control. In the absence of such changes, a review should be conducted annually. This report documents the annual review of the work place air monitoring (WAM) program for Solid Waste Project (SWP),

\subsection{SCOPE}

The criteria, standards, and requirements contained in this document apply only to radioactive airborne particulate sampling in the work place. In addition, this document only evaluates those facilities managed by SWP including the following: T Plant, CWC, and Burial Grounds. SWP previously managed the TRUSAF; however, the facility is currently not being used for operational activities and management responsibility has been transferred to Transition Programs Division (TPD) by "The 224-T Building Memorandum of Agreement," executed on March 12, 1999 (FDH 1999). Conclusions concerning compliance to requirements and changes necessary for compliance apply only to SWP.

\subsection{TECHNICAL BASIS FOR REQUIRING WORK PLACE AIR MONITORING}

FDH ensures compliance with regulatory and contractual requirements for WAM through the procedure entitled Work Place Air Monitoring (FDH 1997b). Contained within the site wide procedure are criteria for determining when air sampling or air monitoring is required as part of a Radiological Control WAM program. Each of these areas are further discussed below.

\subsection{Work Place Air Sampling}

Work place air sampling is required to be performed if the area is classified as occupied (normally occupied, infrequently occupied, or continuously occupied), and an individual is likely to receive an annual intake of two percent or more of the specific annual limit on intake (ALI). An occupied/normally occupied area is defined as a work area where personnel are present for an average 96 minutes per day, 8 hours per week, 104 hours per quarter, and 416 hours per calendar year. Infrequently occupied areas are occupied areas where workers are present less than 2000 hours per year. 
A combination of the following activities/documentation should be used when determining the need for air sampling:

- air sample data,

- radiological survey data,

- $\quad$ source term(s),

- release potential of the source term(s),

- containment or confinement of the source term(s),

- $\quad$ Radiological Work Permit (RWP) constraints, and

- occupancy times.

Using Article 555(2) of the HSRCM and HNF-PRO-331, two percent of the ALI equates to 40 Derived Air Concentrations (DAC-hour). If one DAC-hour generates $2.5 \mathrm{mrem} / \mathrm{hour}$, then 40 DAC-hour would equate to $100 \mathrm{mrem}$. Specific radionuclide airborne concentrations are as follows (dependent upon time spent in work area):

- $\quad 8.0 \mathrm{E}-11 \mathrm{uCi} / \mathrm{ml}$ for $\mathrm{Pu}-239$ and $8.0 \mathrm{E}-08 \mathrm{uCi} / \mathrm{ml}$ for $\mathrm{Sr}-90$ based on exposure for one hour (instantaneous rate),

- $\quad 4.0 \mathrm{E}-14 \mathrm{uCi} / \mathrm{ml}$ for $\mathrm{Pu}-239$ and $4.0 \mathrm{E}-11 \mathrm{uCi} / \mathrm{ml}$ for $\mathrm{Sr}-90$ based on exposure for an eight hour shift integrated over one year, and

- $\quad 5.3 \mathrm{E}-14 \mathrm{uCi} / \mathrm{ml}$ for Pu-239 and 5.3E-11 uCi/ml for Sr-90 based on exposure for a six hour shift integrated over one year.

For surface contamination, the concentration present must be less than that required to produce two percent of a DAC (which would result in two percent ALI if the area is continuously occupied for 2000 hours). Using a resuspension factor of $1 \mathrm{E}-6 / \mathrm{m}$ (a different value may be used for specific nuclides and material forms when empirical data is available) surface contamination levels required to achieve two percent of DAC in a room is $880 \mathrm{dpm} / 100 \mathrm{~cm}^{2}$ alpha (based on ${ }^{239} \mathrm{Pu}$ ) and $8.8 \mathrm{E} 05 \mathrm{dpm} / 100 \mathrm{~cm}^{2}$ beta-gamma (based on ${ }^{90} \mathrm{Sr}$ ). These values assume surface contamination is present over the entire horizontal surface area of the room and that the room is not ventilated. It should be noted that a work area qualifies as an airborne radioactivity area when the air concentration reaches ten percent of DAC, which equates to surface contamination levels of $4,440 \mathrm{dpm} / 100 \mathrm{~cm}^{2}$ for ${ }^{239} \mathrm{Pu}$ and $4.4 \mathrm{E} 06 \mathrm{dpm} / 100 \mathrm{~cm}^{2}$ for ${ }^{90} \mathrm{Sr}$.

Where significant (enough to result in two percent ALI) airborne radioactive material concentration is possible but the probability of initiating airborne remote, facilities may perform a risk analysis by comparing the calculated risk against the requirement to perform air sampling. Risk is calculated by multiplying potential airborne concentration by the probability of material release. Documents that may be used to assess the probability of material release include, but are not limited to, safety analysis documents and data from previous work evolutions. 


\subsection{Work Place Air Monitoring}

Work place air monitoring using continuous air monitors (CAMs) is required to be performed in normally occupied areas where an individual is likely to be exposed to a concentration of airborne radioactivity exceeding one DAC (one DAC averaged over a single eight hour shift is equivalent to eight DAC-hour) or where there is a need to alert potentially exposed individuals to unexpected increases in airborne radioactivity levels.

A combination of the following activities/documentation should be used when determining the need for air monitoring:

- $\quad$ air sample data,

- occupancy time,

- radiological survey data,

- $\quad$ source term(s),

- release potential of the source term(s),

- containment or confinement of source terms(s), and

- RWP constraints.

Using Article 555(2) of the HSRCM and HNF-PRO-331, eight DAC-h would equate to 20 mrem. Specific radionuclides airborne concentrations equate to the following:

- $\quad 1.6 \mathrm{E}-11 \mathrm{uCi} / \mathrm{ml}$ for $\mathrm{Pu}-239$ and $1.6 \mathrm{E}-08 \mathrm{uCi} / \mathrm{ml}$ for $\mathrm{Sr}-90$ based on exposure for a one hour shift (instantaneous),

- $\quad 2.0 \mathrm{E}-12 \mathrm{uCi} / \mathrm{ml}$ for $\mathrm{Pu}-239$ and $2.0 \mathrm{E}-09$ for $\mathrm{Sr}-90$ based on exposure for an eight hour shift integrated over one year, and

- $\quad 2.7 \mathrm{E}-12 \mathrm{uCi} / \mathrm{ml}$ for $\mathrm{Pu}-239$ and $2.7 \mathrm{E}-09 \mathrm{uCi} / \mathrm{ml}$ based on exposure for a six hour shift integrated over one year.

In terms of surface contamination levels that equates to $3.6 \mathrm{E} 05 \mathrm{dpm} / 100 \mathrm{~cm}{ }^{239} \mathrm{Pu}$ and $3.6 \mathrm{E} 08 \mathrm{dpm} / 100 \mathrm{~cm}^{2}{ }^{90} \mathrm{Sr}$.

When evaluating the need for work place air monitoring, the use of protection factors for workers wearing respiratory protection may be considered . In addition, where potentially significant (one DAC averaged over eight hours) airborne concentrations are possible but the probability of initiating airborne is remote, facilities may perform a risk analysis by comparing the calculated risk against the requirement to perform air monitoring with CAMs. Risk is calculated by multiplying potential airborne concentration by the probability of material release. 


\subsection{SOLID WASTE PROJECTS OPERATIONS}

SWP manages operations at the T Plant Complex (treatment), CWC (storage facility), and Burial Grounds (disposal facility). Each of these facilities is discussed below. Additional information regarding these facilities can be found in the interim safety basis (ISB) documentation for each facility.

\subsection{T Plant Complex (Treatment Facility)}

The T Plant Complex is located at the north side of the 200 West Area. The T Plant Complex consists of several facilities whose mission is to receive, repackage, decontaminate, and treat solid waste that is generated on and offsite of the Hanford Site. The T Plant Complex consists of two primary decontamination facilities (221-T and 2706-T) and various support facilities. A more detailed description of several buildings located within the T Plant Complex is presented below.

\subsubsection{1-T Building}

The 221-T Building contains a canyon area, supporting galleries, and Head-End. The canyon area provides services in radioactive decontamination, reclamation, and decommissioning of process equipment contaminated with fission products. The canyon contains inactive processing areas and an active spent fuel storage pool. A canyon crane supports maintenance and operations activities. The cab of the crane operates in the crane way which is within canyon air space. The crane cab uses high-efficiency particulate air (HEPA) filtered supply ventilation to provide "clean" air to the crane. The extreme north end of 221-T includes the "Head End" portion of the building which has been separated from the canyon by a wall and is independently ventilated. The Head End was used as a sodium test facility by Pacific Northwest National Laboratories (PNNL) and is currently being used for opening and repackaging radioactive waste at T Plant. The galleries provide support to facility processes and include: Operating, Pipe, and Electrical galleries. Air is exhausted from these galleries to the environment through a series of unfiltered wall exhausters.

\subsubsection{1-TA Building}

The two ventilation supply fans for the 221-T canyon are located in this building. Supply air conditioning equipment is also located in this building.

\subsubsection{1-T Building}

This building is the office building for T Plant. The building provides offices on three floors (the third floor is currently vacant), a machine shop, chemical make-up area, an instrument shop, mechanical equipment rooms, electrical, and rigger shops. This building is supplied with a single conditioned air system and is maintained at positive air pressure, which directs air flow into the adjacent galleries. 


\subsubsection{6-T, 2706-TA, 2706-TB Buildings}

The 2706-T building was constructed in 1959 for low-level radioactive decontamination activities. The facility is used to decontaminate buses, trucks, automobiles, heavy equipment, and plant process equipment. Treatment activities such as segregation, repackaging, and verification of low-level and low-level mixed waste boxes and drums are also conducted. HEPA filtered exhaust is provided by a single dedicated stack. Inside air is cooled using four recirculating systems. Main features of the facility include a railroad pit over which low-level decontamination activities are performed. Two roll up steel doors provide access to the railroad pit.

An addition to the 2706-T Building, designated 2706-TA, was installed over the facility storage pad located west of the existing 2706-T building. The 2706-TA Building has undergone significant modification since originally built. Modifications include an exhaust ventilation system and liquid extraction system similar to 2706-T. Treatment activities previously performed at the Head End of 221-T can now be performed in 2706-TA.

The 2706-TB building was constructed adjacent to the 2706-TA Filter Room to provide a facility for collection of the liquid effluent from decontamination operations in 2706- $T$ and 2706TA. The building contains two storage tanks for holding the collected effluent.

\subsection{Central Waste Complex (Storage Facility)}

The CWC is located at the west side of the 200 West Area. The CWC is a multifacility complex that receives and stores newly generated low-level waste (LLW), low-level mixed waste (LLMW), transuranic (TRU) waste, and TRU mixed waste. Facilities included within the CWC include the following:

- Waste receiving and staging area (outside area only);

- $\quad$ Mixed waste storage pad (MWSP) (outside area only);

- 2420-W cask storage pad;

- $\quad$ Low-flashpoint mixed waste (LFMW) storage modules;

- $\quad$ South alkali metal (SAM) storage modules;

- Alkali metal waste (AMW) storage modules;

- 2727-W Sodium Storage facility;

- $\quad$ Mixed waste storage facility (Buildings 2402-W and 2402-WB through-WL);

- $\quad$ Mixed waste storage facility (Buildings 2403-WA through 2403-WD);

- $\quad$ Mixed waste storage facility (Buildings 2404-WA through 2404-WC); and

- $\quad 2120-W A$ and 2120-WB Sprung structures (nonradioactive storage only).

A brief description of the main operational buildings is presented below. 


\subsubsection{2-W Series}

The buildings were designed to meet the requirements for hazardous, mixed, and radioactive wastes. Only compatible wastes will occupy any one building at any one time. Deviations from this policy are addressed on a case-by-case basis to determine isolation protocols for incompatible wastes.

\subsubsection{3-W Series}

Phases 1, 3, and 4 (2403-WA, 2403-WB, 2403-WC) are all the same design $\left(34,000 \mathrm{ft}^{2}\right)$ and accommodate approximately 11,616 (55-gal) drums. Phase $2(2403-\mathrm{WD})$ is larger $(55,250$ $\mathrm{ft}^{2}$ ) and accommodates approximately 20,592 (55-gal) drums (currently a large area of 2403-WD is devoted to the storage of two overpacked air lances from tank farms). Each facility contains four separate quadrants for managing various waste categories. Each facility was designed to meet all of the requirements for hazardous, mixed, and radioactive wastes. Only compatible wastes will occupy one zone at any one time, unless proper precautions are taken.

\subsubsection{4-W Series}

The 2404-W facility buildings (2404-WA, -WB and -WC) provide $\approx 6,000 \mathrm{~m}^{2}$ $\left(64,800 \mathrm{ft}^{2}\right)$ of net storage space for $208 \mathrm{~L}$ (55-gal) drums and $322 \mathrm{~L}$ (85-gal) drum overpacks of LLW, LLMW, PCBs, TRU waste, suspect TRU waste, and TRU mixed waste. The 2404-W buildings are similar in construction and operation to the $2403-\mathrm{W}$ storage facility buildings.

\subsection{Burial Grounds (Disposal Facility)}

The 200 Area Burial Grounds are classified as a landfill and cover a total area of approximately 594 acres. The landfill is divided into eight burial grounds located in either the 200 East or 200 West Area. Each burial ground is comprised of a number of trenches. Two burial grounds are located in the 200 East Area: 218-E-10 and 218-E-12B Burial Grounds. The following burial grounds are located in the 200 West Area:

- $\quad 218-W-3 A$ Burial Ground,

- 218-W-3AE Burial Ground,

- $218-W-4 B$ Burial Ground,

- 218-W-4C Burial Ground,

- $\quad 218-W-5$ Burial Ground, and

- 218-W-6 Burial Ground.

Solid Waste, designated LLW, LLMW, TRU, or TRU-mixed waste, has been disposed of in the burial grounds since 1960 . 


\subsection{WORK PLACE AIR MONITORING EVALUATION}

The treatment, storage, and disposal facilities were evaluated against the WAM criteria listed in Section 3.0. Results of the evaluation are summarized below.

\subsection{T Plant Complex}

A review of the routine radiological survey program was conducted at $T$ Plant to identify work areas that contain potential radiological source terms. These areas included Radioactive Material Areas (RMAs), Radiological Buffer Areas (RBAs), Contamination Areas (CAs), Airborne Radioactivity Areas (ARAs), High Contamination Areas (HCAs), and Fixed Contamination Areas (FCAs) and are listed in Table 1.0. Using the baseline list of radiological work areas, information was obtained from Radiological Control, Operations, and Maintenance to define an average occupancy time for each work area, which has been summarized and included in Table 1.0. Those areas that were identified as exceeding the occupancy criteria of greater than 96 minutes per day were further evaluated to determine the potential for exceeding two percent of the ALI or one DAC for ${ }^{239} \mathrm{Pu}$ and ${ }^{90} \mathrm{Sr}$. These areas included the following:

- Electrical Gallery, Sections 2 - 19 (FCA),

- Electrician's Shop, Back Room (FCA/CA),

- $\quad$ Pipe Gallery, Sections 2 - 16 (FCA),

- Operating Galleries, Sections 2 - 20 (FCA/CA for Section 15),

- Canyon Crane Deck and Craneway (HRA/ARA/HCA),

- Head End Vessel Area (RMA/RBA/FCA),

- Head End Greenhouse (CA),

- $\quad$ ACES Office, Room 101 (RMA),

- MO-433 (RMA/RBA/CA),

- 2706-T, and

- 2706-TA.

This listing incorporates changes resulting from occupancy times received from Radiological Control, Operations and Maintenance for FY 1999. The 221-T Tunnel did not qualify for further evaluation based on lack of occupancy.

Removable contamination levels (using available data at the plant) were identified from the routine radiological survey program for those areas identified as meeting the occupancy criteria and were evaluated against two percent of one $\operatorname{DAC}\left(8.8 \mathrm{E} 02 \mathrm{dpm} / 100 \mathrm{~cm}^{2}\right.$ alpha and $8.8 \mathrm{E} 05$ $\mathrm{dpm} / 100 \mathrm{~cm}^{2}$ beta-gamma). The maximum surface contamination level was $2,000 \mathrm{dpm} / 100 \mathrm{~cm}^{2}$ 
Table 1.0 List of Radioactive Material Areas, Radiological Buffer Areas, and Contamination Areas

\begin{tabular}{|c|c|c|c|c|}
\hline \multirow{2}{*}{$\begin{array}{l}\text { Building } \\
\text { No. }\end{array}$} & \multirow{2}{*}{ Location } & \multicolumn{3}{|c|}{ Time Spent in Area (h) } \\
\hline & & RCTs & Ops & Maint \\
\hline 211-T & 211-T Tank (RMA/RA) & $1.0 / \mathrm{wk}$ & 0.00 & 0.00 \\
\hline $211-\mathrm{T}$ & $\begin{array}{l}\text { Hazardous Waste Storage, Caged Area } \\
\text { (RMA) }\end{array}$ & $1.0 / \mathrm{wk}$ & $0.5 / \mathrm{wk}$ & 0.00 \\
\hline $211-\mathrm{T}$ & 211-T Sump Pit and Covers (RBA/CA) & $0.5 / \mathrm{wk}$ & $1.0 / \mathrm{qtr}$ & 0.00 \\
\hline 214- $\mathrm{T}$ & 214-T (RMA) & $1.0 / \mathrm{wk}$ & $1.0 / \mathrm{wk}$ & $1.0 / \mathrm{mo}$ \\
\hline $211-\mathrm{T}$ & $\begin{array}{l}\text { 211-T Tanker Truck Storage } \\
\text { (RMA/RA) }\end{array}$ & $1.0 / \mathrm{wk}$ & 0.00 & 0.00 \\
\hline N/A & Boneyard (RMA) & $2.0 / \mathrm{wk}$ & 0.00 & 0.00 \\
\hline N/A & Railroad Cut (CA/RBA) & $2.5 / \mathrm{wk}$ & $1.0 / \mathrm{wk}$ & 0.00 \\
\hline $\begin{array}{l}221-\mathrm{T} \\
\text { Complex }\end{array}$ & R-17 (indoor/outdoor) (RMA/RBA/CA) & $1.0 / \mathrm{wk}$ & 0.00 & $1.0 / \mathrm{qtr}$ \\
\hline $\mathrm{N} / \mathrm{A}$ & $\begin{array}{l}\text { South End } 221 \text {-T, East Side of } \\
\text { 221-TA (RMA) }\end{array}$ & $0.5 / \mathrm{wk}$ & $5 \mathrm{~min} / \mathrm{wk}$ & $1.0 / \mathrm{qtr}$ \\
\hline N/A & 291-T-1 Stack CAM Cabinet (RMA) & $1.0 / \mathrm{wk}$ & 0.00 & $2.0 / \mathrm{mo}$ \\
\hline N/A & 291-T-1 Stack Fan Nos. 1 and 2 (RMA) & $0.5 / \mathrm{wk}$ & 0.00 & $1.0 / \mathrm{wk}$ \\
\hline N/A & 291-T Main Stack (CA/RBA) & $1.0 / \mathrm{wk}$ & 0.00 & $2.0 / \mathrm{yr}$ \\
\hline $\begin{array}{l}221-\mathrm{T} \\
\text { Roof }\end{array}$ & 296-T-13 Stack Area (RBA/CA/FCA) & $1.0 / \mathrm{wk}$ & 0.00 & 0.00 \\
\hline N/A & $\begin{array}{l}\text { Connex Box Near 221-TA, Used } \\
\text { Laundry Storage (RMA) }\end{array}$ & $0.5 / \mathrm{wk}$ & $0.5 / \mathrm{wk}$ & 0.00 \\
\hline $2716-\mathrm{T}$ & $\begin{array}{l}\text { Tunnel Change Trailer } \\
\text { (RMA/RBA/CA) }\end{array}$ & $2.0 / \mathrm{wk}$ & $1.0 / \mathrm{wk}$ & $1.0 / \mathrm{wk}$ \\
\hline $221-\mathrm{T}$ & Tunnel (CA) & $2.0 / \mathrm{wk}$ & $1.0 / \mathrm{wk}$ & $4.0 / \mathrm{mo}$ \\
\hline $271-\mathrm{T}$ & $\begin{array}{l}\text { Rm 106, V-Block Source Storage } \\
\text { (RMA) }\end{array}$ & $0.5 / \mathrm{wk}$ & 0.00 & 0.00 \\
\hline
\end{tabular}




\begin{tabular}{|c|c|c|c|c|}
\hline \multirow{2}{*}{$\begin{array}{l}\text { Building } \\
\text { No. }\end{array}$} & \multirow{2}{*}{ Location } & \multicolumn{3}{|c|}{ Time Spent in Area (h) } \\
\hline & & RCTs & Ops & Maint \\
\hline $221-\mathrm{T}$ & Electrical Gallery, Sections 2-19 (FCA) & $1.0 / \mathrm{wk}$ & $0.5 /$ day & $\begin{array}{l}>96 \mathrm{~min} / \\
\text { day }\end{array}$ \\
\hline $221-\mathrm{T}$ & $\begin{array}{l}\text { Section } 15, \mathrm{P} / \mathrm{G}, \mathrm{RCT} \text { Storage Cabinet } \\
\text { (RMA) }\end{array}$ & $0.5 / \mathrm{wk}$ & 0.00 & 0.00 \\
\hline $221-\mathrm{T}$ & Section 11, P/G, Mask Storage (RMA) & $0.5 / \mathrm{wk}$ & 0.00 & 0.00 \\
\hline $221-\mathrm{T}$ & $\begin{array}{l}\text { Section } 19 \text { and } 20, \mathrm{O} / \mathrm{G} \text { including } \\
\text { stairwell (RMA/FCA/RBA/CA) }\end{array}$ & $\begin{array}{l}>96 \\
\mathrm{~min} / \text { day }\end{array}$ & $\begin{array}{l}>96 \\
\mathrm{~min} / \text { day }\end{array}$ & $2.0 / \mathrm{wk}$ \\
\hline $221-\mathrm{T}$ & $\begin{array}{l}\text { Electrician's Shop, Back Room } \\
\text { (FCA/CA) }\end{array}$ & $1.0 / \mathrm{wk}$ & 0.00 & $\begin{array}{l}>96 \mathrm{~min} / \\
\text { day }\end{array}$ \\
\hline 221-T & $\begin{array}{l}\text { Electrical Gallery, Section 20, Hot shop } \\
\text { (RBA/RMA) }\end{array}$ & $1.0 / \mathrm{wk}$ & 0.00 & $3.0 / \mathrm{wk}$ \\
\hline $221-\mathrm{T}$ & Pipe Gallery, Sections 2-16 (FCA) & $1.0 / \mathrm{wk}$ & $\begin{array}{l}>96 \mathrm{~min} / \\
\text { day }\end{array}$ & $\begin{array}{l}>96 \mathrm{~min} / \\
\text { day }\end{array}$ \\
\hline $221-\mathrm{T}$ & $\begin{array}{l}\text { Operating Galleries, Sections 2-15 } \\
\text { (FCA) Section } 15 \text { contains CA }\end{array}$ & $\begin{array}{l}>96 \\
\mathrm{~min} / \text { day }\end{array}$ & $\begin{array}{l}>96 \mathrm{~min} / \\
\text { day }\end{array}$ & $\begin{array}{l}>96 \mathrm{~min} / \\
\text { day }\end{array}$ \\
\hline $221-\mathrm{T}$ & $\begin{array}{l}\text { Section 11, Craneway Entrance } \\
\text { (RMA/RBA/CA) }\end{array}$ & $1.0 \mathrm{~h} / \mathrm{wk}$ & $1.0 / 5 \mathrm{mo}$ & $3.0 / \mathrm{mo}$ \\
\hline $221-\mathrm{T}$ & Canyon Crane Cab (CA) & $2.0 / \mathrm{mo}$ & $1.0 / 5 \mathrm{mo}$ & $2.0 / \mathrm{mo}$ \\
\hline $221-\mathrm{T}$ & $\begin{array}{l}\text { Canyon Deck and Craneway } \\
\text { (HRA/ARA/HCA) }\end{array}$ & $\begin{array}{l}>96 \mathrm{~min} / \\
\text { day }\end{array}$ & $\begin{array}{l}>96 \mathrm{~min} / \\
\text { day }\end{array}$ & $2.0 / \mathrm{wk}$ \\
\hline N/A & $\begin{array}{l}\mathrm{R}-3 \text { to } \mathrm{R}-5 \text { (RMA), R-7, R-9, R-11, R- } \\
15, \mathrm{R}-19\end{array}$ & $3.0 / \mathrm{wk}$ & $1.5 / \mathrm{wk}$ & $1.0 / \mathrm{mo}$ \\
\hline $221-\mathrm{T}$ & $\begin{array}{l}\text { Head End Vessel Area, includes HEPA } \\
\text { Vacuum Storage (RMA/RBA/FCA) }\end{array}$ & $\begin{array}{l}>96 \mathrm{~min} / \\
\text { day }\end{array}$ & $\begin{array}{l}>96 \mathrm{~min} / \\
\text { day }\end{array}$ & $2.0 / \mathrm{wk}$ \\
\hline 221-T & Head End Greenhouse (CA) & $\begin{array}{l}>96 \mathrm{~min} / \\
\text { day }\end{array}$ & $\begin{array}{l}>96 \mathrm{~min} / \\
\text { day }\end{array}$ & $1.0 / \mathrm{wk}$ \\
\hline $221-\mathrm{T}$ & $\begin{array}{l}221-\mathrm{T} \text { Shed (RBA/CA) and Concrete } \\
\text { Pad (FCA) }\end{array}$ & $0.5 / \mathrm{wk}$ & 0.00 & 0.00 \\
\hline $221-\mathrm{T}$ & $\begin{array}{l}\text { Non-Destructive Cleaning Trailer } \\
\text { (CA/RBA) }\end{array}$ & $0.5 / \mathrm{wk}$ & 0.00 & 0.00 \\
\hline
\end{tabular}




\begin{tabular}{|c|c|c|c|c|}
\hline \multirow{2}{*}{$\begin{array}{c}\text { Building } \\
\text { No. }\end{array}$} & \multirow{2}{*}{ Location } & \multicolumn{3}{|c|}{ Time Spent in Area (h) } \\
\hline & & RCTs & Ops & Maint \\
\hline $221-\mathrm{T}^{\prime}$ & Unused Laundry Storage Area & $0.5 / \mathrm{wk}$ & 0.00 & 0.00 \\
\hline $221-\mathrm{T}$ & $\begin{array}{l}\text { Contamination Area attached to } 222-\mathrm{T} \\
\text { next to shotcrete area }\end{array}$ & $0.5 / \mathrm{wk}$ & 0.00 & 0.00 \\
\hline $221-\mathrm{T}^{\prime}$ & $\begin{array}{l}\text { Head End Clean Laundry Storage } \\
\text { (RMA) }\end{array}$ & $0.5 / \mathrm{wk}$ & $1.0 / \mathrm{wk}$ & 0.00 \\
\hline 221-TA & 221-TA (RBA/CA) & $1.0 / \mathrm{wk}$ & 0.00 & $1.0 / \mathrm{qtr}$ \\
\hline $\begin{array}{l}221-\mathrm{T} / \\
271-\mathrm{T}\end{array}$ & Stairwells & $1.0 / \mathrm{wk}$ & $1.0 / \mathrm{wk}$ & $1.0 / \mathrm{mo}$ \\
\hline $271-\mathrm{T}$ & Tool Room, Drawer (RMA) & $1.0 / \mathrm{wk}$ & 0.00 & As required \\
\hline $271-\mathrm{T}$ & ACES Office, Room 101 (RMA) & $\begin{array}{l}>96 \mathrm{~min} / \\
\text { day }\end{array}$ & $0.5 /$ day & $0.5 /$ day \\
\hline $271-\mathrm{T}$ & FCA Storage Room No. 16 (FCA/CA) & $0.5 / \mathrm{wk}$ & $0.5 / \mathrm{wk}$ & $1.0 / \mathrm{mo}$ \\
\hline $292-\mathrm{T}$ & Old Lab (CA) & $1.0 / \mathrm{wk}$ & 0.00 & 0.00 \\
\hline $\begin{array}{l}\text { 2706-T } \\
\text { Complex }\end{array}$ & $\begin{array}{l}\text { RCV Parking Northwest Side of } \\
\text { 2706-T Yard (RMA) }\end{array}$ & $0.5 / \mathrm{wk}$ & $1.0 / \mathrm{wk}$ & 0.00 \\
\hline $\begin{array}{l}\text { 2706-T } \\
\text { Complex }\end{array}$ & $\begin{array}{l}\text { Asphalt Pad West of } 2706-\mathrm{T} \\
\text { (RMA/RBA) }\end{array}$ & $2.0 / \mathrm{wk}$ & $1.0 / \mathrm{wk}$ & $1.0 / \mathrm{wk}$ \\
\hline $\begin{array}{l}\text { 2706-T } \\
\text { Complex }\end{array}$ & 2706-T Yard (RMA/RBA/CA) & $1.0 / \mathrm{wk}$ & $1.0 /$ day & 0.00 \\
\hline $\begin{array}{l}\text { 2706-T } \\
\text { Complex }\end{array}$ & $\begin{array}{l}\text { Concrete Railroad Pad Inside 2706-T } \\
\text { Fence (RMA/FCA) }\end{array}$ & $2.0 / \mathrm{wk}$ & 0.00 & 0.00 \\
\hline $\begin{array}{l}\text { 2706-T } \\
\text { Complex }\end{array}$ & $\begin{array}{l}\text { MO-433 (RMA/RBA/CA) and MO-739 } \\
\text { Change Trailers (RMA/RBA) }\end{array}$ & $3.0 / \mathrm{wk}$ & $\begin{array}{l}>96 \mathrm{~min} / \\
\text { day }\end{array}$ & $3.5 / \mathrm{wk}$ \\
\hline $\begin{array}{l}\text { 2706-T } \\
\text { Complex }\end{array}$ & 2706-T and 2706-TA (RBA/RMA/CA) & $\begin{array}{l}>96 \mathrm{~min} / \\
\text { day }\end{array}$ & $\begin{array}{l}>96 \mathrm{~min} / \\
\text { day }\end{array}$ & $\begin{array}{l}>96 \mathrm{~min} / \\
\text { day }\end{array}$ \\
\hline $2706-\mathrm{T}$ & Maintenance Shop (CA) & $3.0 / \mathrm{wk}$ & $1.0 / \mathrm{wk}$ & $4.0 / \mathrm{wk}$ \\
\hline $2706-\mathrm{T}$ & Stack Cabinet (RMA) & $2.0 / \mathrm{wk}$ & 0.00 & $2.0 / \mathrm{mo}$ \\
\hline N/A & Storage Area West of MO-906 (RMA) & $1.0 / \mathrm{wk}$ & 0.00 & 0.00 \\
\hline
\end{tabular}


at the Canyon Crane Deck and Craneway. No surface contamination data exceeded workplace air sampling or monitoring criteria.

Air sample data documenteed in the EDP Air Sampling and Monitoring Tracking and Trending book, as well as air sample data generated during job-specific coverage were reviewed. As listed in Table 2.0, those areas identified with assigned EDP codes include: Crane Cab, Operations Gallery Section 20, Tunnel, Head End Vessel Area, 2706-T Facility, 2706-TA Facility, and Act 1. These air samplers were placed into service prior to current work place air sampling and monitoring requirements.

No air sample results collected as part of the EDP Air Sample Tracking and Trending program exceeded workplace air sampling or monitoring criteria. Routine air sample data from the Head End Vessel Area fixed-head air sampler indicated maximum air concentrations of $5.93 \mathrm{E}-15 \mu \mathrm{Ci} / \mathrm{ml}$ alpha and $6.66 \mathrm{E}-14 \mu \mathrm{Ci} / \mathrm{ml}$ beta-gamma.

Air samples were removed and counted from general area room CAMs located at Head End during two separate work days. Typically, air sample media removed from the general area room CAMs are discarded and not counted. In both instances, air sample data were above $10 \%$ DAC; however, an approximate $2: 1$ ratio of beta-gamma radioactivity to alpha radioactivity was exhibited for several decay counts indicating that radon may be the most likely cause of the elevated airborne levels. Air sampling results from the fixed-head located in the same general area are used as the controlling sample point for determining airborne radioactivity levels.

Job-specific air sampling at Head End Greenhouse using a fixed-head air sampler indicated maximum air concentrations of $2.94 \mathrm{E}-11 \mu \mathrm{Ci} / \mathrm{ml}$ alpha and $6.59 \mathrm{E}-11 \mu \mathrm{Ci} / \mathrm{ml}$ beta-gamma, with corresponding averages of $2.88 \mathrm{E}-12 \mu \mathrm{Ci} / \mathrm{ml}$ and $4.96 \mathrm{E}-12 \mu \mathrm{Ci} / \mathrm{ml}$, respectively. Considering use of respiratory protection ( $\mathrm{PF}=100$ ) for work in the Head End Greenhouse, these values drop below criteria requiring workplace monitoring; however, air sampling would be warranted.

Job-specific air sampling at the Canyon Crane Deck and Craneway indicated average air concentrations of $4.4 \mathrm{E}-13 \mu \mathrm{Ci} / \mathrm{ml}$ for alpha and $2.5 \mathrm{E}-12 \mu \mathrm{Ci} / \mathrm{ml}$ for beta-gamma. Considering the use of respiratory protection when entering the Canyon $(\mathrm{PF}=100)$, these values are below the criteria for workplace air sampling and monitoring.

It should be noted that several CAMs were removed in FY 1998 in accordance with recommendations contained in Internal Memorandum 32A50-EJM-97-006, " Removal of Continuous Air Monitors at T Plant." Specific CAMs removed included those in the Electrical Gallery, the Pipe Gallery and the Operating Gallery.

The credible accident that would contribute the largest dose to an onsite worker was used to determine whether there is a need to alert potentially exposed individuals to unexpected increases in airborne radioactivity levels. The Interim Safety Analysis for Solid Waste Facilities (T Plant), Rev.1 (FDH 1998a) was used in the evaluation to develop the risk value. The bounding effective 
Table 2.0. Baseline List of Air Sampling and Monitoring at T Plant.

\begin{tabular}{|c|c|c|}
\hline $\begin{array}{l}\text { EDP } \\
\text { Code }\end{array}$ & Location & $\begin{array}{c}\text { Type of } \\
\text { Sampler/Monitor }\end{array}$ \\
\hline T-759 & 221-T Operating Gallery, Section 20 & Beta CAM \\
\hline $\mathrm{T}-791$ & 221-T Crane Cab, Section 11 & Beta CAM \\
\hline $\mathrm{T}-001^{\mathrm{a}}$ & 221-T Tunnel & Beta CAM (2) \\
\hline $\mathrm{T}-018^{\mathrm{a}}$ & 221-T Tunnel & Alpha CAM (2) \\
\hline None & 221-T Canyon Deck, Section 15 & Beta CAM \\
\hline None & 221-T Canyon Deck, Section 15 & Alpha CAM \\
\hline None & 221-T Head End - Greenhouse & Beta CAM \\
\hline None & 221-T Head End - Greenhouse & Alpha CAM \\
\hline None & 221-T Head End - Vessel Area & Beta CAM \\
\hline None & 221-T Head End - Vessel Area & Alpha CAM \\
\hline $\mathrm{T}-016$ & 221-T Head End & Fixed Head \\
\hline $\mathrm{T}-785^{\mathrm{b}}$ & 291-T-1 Stack & Record Sampler \\
\hline $\mathrm{T}-004$ & 2706-T Bay Area & Beta CAM \\
\hline $\mathrm{T}-159$ & 2706-T Maintenance Room & Fixed Head \\
\hline $\mathrm{T}-161$ & 2706-T Act I Fan Room & Fixed Head \\
\hline$T-162$ & 2706-TA & Beta CAM \\
\hline $\mathrm{T}-154^{\mathrm{b}}$ & 2706-T Stack & Record Sampler \\
\hline
\end{tabular}

One set of CAMs is for general area monitoring; a second set is used for breathing air sampling.

b Record sampler is required per Air and Water Services (stack monitoring for environmental purposes). 
dose equivalent results from an accidental spray release from Tank 15-1 and was determined to be 2.32 rem to a worker located approximately 500 meters $(m)$ away. This scenario has a $2.0 \mathrm{E}-5$ probability of occurring. Using these values, the resulting dose per year is the following:

$$
(2.32 \mathrm{rem})(1000 \mathrm{mrem} / 1 \mathrm{rem})(2.0 \mathrm{E}-5 / \text { year })=0.05 \mathrm{mrem} / \text { year. }
$$

A comparison of the resulting dose risk based on ISB values $(0.05 \mathrm{mrem} /$ year $)$ against the one DAC criteria (20 mrem) indicates the resulting risk in terms of dose to a worker located approximately 500 meters away would be below the one DAC criteria. Based on the nature of the accident (liquid release) and the low dose risk, air monitoring using CAMs is not an effective or necessary mechanism for alerting potentially exposed individuals to unexpected increases in airborne radioactive material from this accident.

\subsection{Central Waste Complex}

A review of operational information of the CWC indicated that personnel may or may not spend greater than 96 minutes per day in any given building. Therefore, for purposes of this evaluation it was assumed that occupancy in each of the CWC buildings met the definition of "occupied".

Based on a recommendation in the 1998 annual revision to the work place air sampling document, several fixed-head air samplers were removed. However, air sampling is still being conducted per the environmental air permit for the facility. Review of available air sample records indicated radioactive air concentrations continued to be significantly below two percent of the ALI and one DAC (eight DAC-hour per eight hour shift) for ${ }^{239} \mathrm{Pu}$ and ${ }^{90} \mathrm{Sr}$. In addition, routine radiological survey data did not indicate any removable surface contamination present in any of the facilities; thereby not requiring air sampling and monitoring.

The credible accident that would contribute the largest dose to an onsite worker was used to determine whether there is a need to alert potentially exposed individuals to unexpected increases in airborne radioactivity levels. The interim safety basis for CWC (FDH 1998b) was used in the evaluation to develop the risk value. The bounding effective dose equivalent resulting from a truck crashing and igniting a fire was determined to be 57 rem to a worker located approximately 800 meters from the complex. This scenario has a $4.0 \mathrm{E}-6$ probability of occurring. Using these values, the resulting dose per year is:

$$
(57 \mathrm{rem})(1000 \mathrm{mrem} / 1 \mathrm{rem})(4.0 \text { E-6/year })=0.23 \mathrm{mrem} / \text { year. }
$$

A comparison of the resulting dose risk based on ISB values $(0.23 \mathrm{mrem} /$ year $)$ against the one DAC criteria (20 mrem) indicates the resulting risk in terms of dose to a worker located approximately 800 meters away would be below the one DAC criteria. Based on the nature of the accident (truck accident and fire) and the low dose risk, air monitoring using CAMs is not an effective or necessary mechanism for alerting potentially exposed individuals to unexpected increases in airborne radioactive material. 


\subsection{Burial Grounds}

A review of operational information for the Burial Grounds indicated that although personnel may spend greater than 96 minutes per day in any given trench, the work area is located outdoors where airborne particulates are not expected to concentrate and exceed two percent of the ALI or one DAC (assuming nonintrusive work activities are being conducted). Job-specific air sampling data was reviewed and indicated air concentrations did not approach those which would require sampling and monitoring criteria.

The credible accident that would contribute the largest dose to an onsite worker was used to determine whether there is a need to alert potentially exposed individuals to unexpected increases in airborne radioactivity levels. The Solid Waste Burial Grounds Interim Safety Basis, Rev. 3 (FDH 1998c) was used in the evaluation to develop the risk value. The bounding effective dose equivalent resulting from a drum exploding was determined to be 75 rem to a worker located approximately 800 meters from Burial Grounds. This scenario has a $1.0 \mathrm{E}-06$ probability of occurring. Using these values, the resulting risk in terms of dose per year is:

$$
(75 \mathrm{rem})(1000 \mathrm{mrem} / 1 \mathrm{rem})(1.0 \mathrm{E}-6 / \text { year })=0.08 \mathrm{mrem} / \text { year }
$$

A comparison of the resulting dose risk based on ISB values $(0.08 \mathrm{mrem} /$ year) against the one DAC criteria (20 mrem) indicates the resulting risk in terms of dose to a worker located approximately 800 meters away would be below the one DAC criteria. Therefore, work place air monitoring is not required for the Burial Grounds.

\subsection{CONCLUSIONS}

Results of the evaluation indicated that no work locations within Solid Waste Projects were identified as meeting criteria for workplace air sampling and monitoring. In June, 1999, decontamination and verification activities are expected to be initiated at the 2706-T and 2706TA facilities. It is recommended that CAMs be placed in both facilities to establish baseline air concentrations. A CAM is recommended to be used for sampling and monitoring purposes instead of a fixed-head air sampler given the type of activities to be performed and the unknown effect the sparging units will have on airborne concentrations. It is recommended that air sampling and monitoring units that have historically been present at 2706-T and 2706-TA be continued to support baseline airborne concentration levels for the facility. Smoke testing is scheduled to be performed the beginning of June, 1999, and the location of the CAMs will be dependent upon air flow patterns identified during smoke tests. In addition, a decision as to whether additional administrative controls will be necessary for operation of the air recirculation units will be determined following completion of smoke testing. 
It is recommended that the continued use of work place air sampling and monitoring be reevaluated and significantly downgraded for the Treatment Facility. Specifically, the use of fixed-head and general area CAMs at the Head End Vessel Area should be reevaluated given the extent of air sampling currently being conducted as part of job-specific work within the Greenhouse. Continued use of the CAM at Section 20 of the Operating Gallery should be reevaluated and consideration given to removal of the instrument given air concentrations observed over the past year. In addition, continued use of workplace CAMs in the Tunnel should be reevaluated and the use of job-specific air sampling considered primarily based on the infrequency of entry. Finally, the canyon is posted as an ARA; however, based on evaluation of data the potential for down posting the area may be pursued.

Routine radiological work place air sampling or monitoring is not required to be conducted at the CWC or Burial Ground Facilities. Using data from the ISBs associated with SWP facilities, none of the facilities exhibited the need to alert personnel to unexpected increases of radioactivity. It should be noted that air sampling will still be required to be conducted at the CWC in support of environmental compliance activities, not routine radiological activities.

Should the radiological conditions change for work being performed at SWP, the requirement for work place air sampling or monitoring should be reevaluated on a case-by-case basis and subsequently documented. 


\subsection{REFERENCES}

FDH, 1997a, Fluor Daniel Hanford Radiation Protection Program, Implementation of Title 10, Code of Federal Regulation, Part 835. HNF-SP-1145, Rev. 2. Fluor Daniel Hanford, Inc., Richland, Washington.

FDH,1997b, Work Place Air Monitoring, HNF-PRO-331, Rev. 0, Fluor Daniel Hanford, Inc., Richland, Washington.

FDH, 1998a, Interim Safety Analysis for Solid Waste Facilities (T Plant), HNF-SD-WM-ISB006, Rev. 1.

FDH, 1998b, Central Waste Complex Interim Safety Basis, HNF-SD-WM-ISB-007, Rev. 1.

FDH, 1998c, Solid Waste Burial Grounds Interim Safety Basis, HNF-SD-WM-ISB-002, Rev. 3.

FDH, 1999, The 224-T Building Memorandum of Agreement, FDH-9951776, Fluor Daniel Hanford, Inc., Richland, Washington.

HSRCM, Hanford Site Radiological Control Manual, Hanford Radiological Control Manual, DOE/RL-96-109, Rev. 0, U. S. DOE, Richland Operations Office, Richland Washington.

Internal Memorandum 32A50-EJM-97-006, "Removal of Continuous Air Monitors at T Plant," Waste Management Federal Services of Hanford Inc., Richland, Washington. 